\title{
POTENSI EDIBLE FILM ANTIMIKROBA SEBAGAI PENGAWET DAGING
}

\section{POTENTIAL OF ANTIMICROBIAL EDIBLE FILM AS MEAT PRESERVATIVES}

\author{
Miskiyah*, Juniawati, dan Evi Savitri Iriani \\ Balai Besar Penelitian dan Pengembangan Pascapanen Pertanian, Bogor, 16114
}

Submitted: 18 February 2015, Accepted: 8 May 2015

\begin{abstract}
INTISARI
Daging merupakan bahan pangan dengan kandungan gizi tinggi sehingga mudah rusak oleh proses mikrobiologis. Penggunaan edible film antimikroba merupakan salah satu cara efektif untuk memperpanjang umur simpan daging segar. Penelitian ini bertujuan untuk mendapatkan formula edible film antimikroba yang berpotensi untuk mengawetkan daging sapi segar. Penelitian terdiri dari beberapa tahapan yaitu 1) pembuatan ekstrak bawang putih segar, 2) ekstraksi gelatin dari kaki ayam, 3) proses formulasi dan pembuatan edible film, dan 4) aplikasi edible film pada daging segar. Edible film antimikroba berbasis gelatin kaki ayam merupakan edible film terbaik yang dapat diaplikasikan pada daging segar. Karakteristik edible film tersebut adalah: warna L: 97,28; elongasi $20 \mathrm{~mm}$; kuat tarik <0,1 kgf; ketebalan $0,06 \mathrm{~mm}$; WVTR 15,49 g/(mm.jam); Aw 0,526; kadar air 22,73\%, dan mempunyai sifat antimikroba karena dapat menghambat pertumbuhan $S$. aureus dan E. coli.
\end{abstract}

(Kata kunci: Antimikroba, Daging, Edible film)

\section{ABSTRACT}

Fresh meat are highly perishable due to their enriched nutrient composition which is easily contaminated by almost any microorganisms. The application of antimicrobial edible films is one of the effective method to extend the shelf life of fresh meat. This study aimed to get antimicrobial edible films formula that have the potential to preserve fresh meat. The study consisted of several steps: 1) research for making a fresh garlic extract, 2) extraction of gelatin from chicken feet, 3) formulation and manufacturing of antimicrobial edible films and 4) the application of edible films on fresh meat. Gelatin-based antimicrobial edible films was the best one that can be applied on fresh meat. Characteristics of the antimirobial edible film: color L 97.28; elongation: $20 \mathrm{~mm}$; tensile strength <0.1 kgf; thickness $0.06 \mathrm{~mm}$; WVTR $15.49 \mathrm{~g} /(\mathrm{mm} . j \mathrm{jm})$; Aw 0.526; moisture content: $22.73 \%$, and has antimicrobial characteristic because of it's inhibition ability to the growth of $S$. aureus and E. coli.

(Key words: Antimicrobial, Edible film, Meat)

\section{Pendahuluan}

Daging mempunyai keterbatasan umur simpan. Selama proses penanganan dan pengolahan mikroorganisme akan masuk ke dalam daging (Newton et al., 1978; Rao dan Ramesh, 1992). Sumber utama kontaminasi mikroorganisme adalah kulit yang tersisa, isi perut, lantai, meja kerja, peralatan, dan perlengkapan pekerja (Garcia-Lopez et al., 1998). Upaya untuk menekan pertumbuhan mikroorganisme pada daging harus dilakukan sejak penyembelihan hingga saat daging tersebut dibeli konsumen dan siap untuk dikonsumsi. Beberapa teknologi seperti

\footnotetext{
${ }^{*}$ Korespondensi (corresponding author):

Telp. +62 81316565322

E-mail: miski_pascapanen2005@yahoo.co.id
}

pendinginan, pembekuan, penggunaan bahan pengawet, iradiasi, penggunaan tekanan tinggi serta pengemasan dianggap mampu menangani masalah tersebut (Zhou et al., 2010). Namun penggunaan tekanan tinggi, pengawet alami serta pengemasan memiliki prospek dinilai lebih baik karena lebih hemat energi dan ramah lingkungan.

Penggunaan berbagai jenis rempahrempah dan minyak atsiri telah digunakan untuk mengawetkan daging seperti eugenol yang berasal dari tanaman cengkeh (Roller et al., 2002) dan ekstrak bawang putih (Hermansyah, 2006). Bawang putih (Allium sativum) termasuk dalam famili Liliaceae, berpotensi sebagai pengawet untuk makanan 
olahan (de Padua et al., 1999). Setidaknya terdapat 33 senyawa sulfur, beberapa enzim, 17 asam amino, dan mineral seperti selenium (Newall et al., 1996) pada bawang putih. Senyawa sulfur tersebut memiliki manfaat sebagai obat dan pengawet alami. Ekstrak bawang putih cukup potensial dalam menghambat $L$. monocytogenes, $E$. coli dan Salmonella (Indu et al., 2006).

Penggunaaan lapisan film yang mengandung bahan antimikroba dapat lebih efisien dalam mengatur proses migrasi bahan aktif ke dalam produk pangan dibandingkan dengan penyemprotan maupun pencelupan. Pencelupan dapat berakibat pada berkurangnya aktivitas antimikroba karena larut dalam matriks makanan ataupun bereaksi dengan komponen pangan seperti protein dan lemak. Permukaan daging yang dikemas dengan lapisan film antimikroba akan senantiasa dilindungi oleh bahan antimikroba sehingga kontaminasi dapat dikurangi untuk memperpanjang umur simpan daging segar (Mauriello et al., 2005). Edible film berfungsi sebagai penghalang selektif terhadap perpindahan air, oksigen, oksidasi lemak dan kehilangan aroma volatil, serta flavor dari makanan (Tapia et al., 2007). Edible film dapat berfungsi sebagai pembawa (carrier) aditif makanan yang bersifat sebagai agen anti pencoklatan, antimikroba, pewarna, pemberi flavor, nutrisi, dan bumbu (Li dan Brath, 1998; Pranoto et al., 2005). Tujuan penelitian ini adalah mendapatkan formula lapisan film antimikroba yang berpotensi untuk mengawetkan daging sapi segar.

\section{Materi dan Metode}

\section{Bahan}

Bahan yang digunakan dalam penelitian ini adalah bawang putih (Allium sativum, sp), gelatin kaki ayam (ceker), sagu aren (Metroxylon sp), pektin, gliserol, CMC, dan tapioka (cassava). Peralatan yang digunakan adalah blender, hot plate, pendingin tegak, kertas saring, gelas piala, buret, gelas ukur, pipet volumetri $5 \mathrm{~mL}$, pipet tetes, panci pemanas, plat kaca, gelas ukur, timbangan, termometer, mixer, kompor pemanas, erlenmeyer asah $250 \mathrm{~mL}$, erlenmeyer $250 \mathrm{~mL}$, pH meter, neraca analitik Sartorius BT-224S, cawan porselin, oven Memmert, tanur, desikator, labu Kjedahl, alat dekstruksi Digestor Stove HYP-1008, alat destilasi Automatic Nitrogen Determinator $K D N-103 F$, dan Soxtech SZC-D.

Bahan kimia yang digunakan antara lain asam asetat $1 \%$, dinatrium tetraborat, asam sulfat pekat, katalis selenium, asam borat $4 \%$, indikator campuran antara indikator bromcresol green dan metil merah dengan perbandingan 10:2, natrium hidroksida $30 \%$, natrium hidroksida $1 \%$, natrium hidroksida $10 \%$, natrium hidroksida $50 \%$, asam klorida $0,1 \mathrm{~N}$, asam klorida $3 \%$, asam klorida $25 \%$, asam klorida $2 \mathrm{~N}$, asam klorida $6 \mathrm{~N}$, pereaksi Luff-Schoorl, kalium iodat, asam sulfat $25 \%$, kalium iodida $20 \%$, larutan kanji 0,5\%, natrium tiosulfat $0,1 \mathrm{~N}$, heksan, etanol dan akuades.

\section{Metode}

Pembuatan ekstrak bawang putih segar. Bawang putih segar dikupas kemudian digiling kasar menggunakan blender, dimaserasi dengan pelarut air selama 30 menit. Filtrat hasil maserasi dipisahkan dengan menggunakan kain saring dan siap digunakan sebagai bahan aktif antimikroba.

Ekstraksi gelatin dari kaki ayam. Kaki ayam dicuci terlebih dahulu kemudian direndam dalam asam asetat $1 \%$ dengan perbandingan 1:3 (berat/volume; w/v) selama 24 jam. Setelah 24 jam kulit kaki ayam tersebut dicuci kembali, kemudian diekstrak dengan akuades dalam waterbath pada suhu $70^{\circ} \mathrm{C}$ selama 20 menit (proses ekstraksi dilakukan sebanyak 2x ekstraksi). Hasil ekstraksi kemudian disaring dengan kain kassa hingga diperoleh gelatin cair dan digunakan untuk formulasi edible film.

Proses pembuatan edible film (modifikasi metode Harris, 1999). Prosedur pembuatan edible film secara umum sebagai berikut: bahan baku ditimbang sesuai formulasi (Tabel 1, Tabel 2, Tabel 3, dan Tabel 4). Gliserol dilarutkan ke dalam akuades pada gelas piala $1000 \mathrm{ml}$ sampai homogen, kemudian dimasukkan pati dan diaduk rata, selanjutnya dimasukkan CMC dan dilakukan pengadukan kembali sampai rata. Selanjutnya supaya suspensi pati merata dilakukan pengadukan menggunakan mixer skala 1 selama 10 menit. Suspensi pati dipanaskan di atas waterbath sambil diaduk sampai mencapai suhu $\pm 65-70^{\circ} \mathrm{C}$ selama 10 menit. Suspensi pati yang sudah mengental tersebut masih banyak mengandung gas terlarut sehingga perlu dilakukan penghilangan gas dengan cara pengadukan secara cepat. Setelah semua gas terlarut 
hilang, suspensi yang telah mengental tersebut kemudian dituang ke pelat kaca pencetak film dan diratakan dengan pelat kaca perata film sampai membentuk lembaran film yang tipis dan rata. Kemudian dibiarkan kering dan dimasukkan ke dalam oven pada suhu $\pm 50^{\circ} \mathrm{C}$ selama 2-3 jam. Setelah diangkat dari oven, edible film dilepas dari cetakan dan diletakkan di atas alas plastik dan dimasukkan ke dalam kantong plastik berkelim.

Tahap I. Penelitian tahap I merupakan uji coba formula edible film yang dilakukan dengan metode trial and error. Edible film dibuat dari bahan-bahan pembentuk film yang terdiri dari tapioka (pati cassava), pati sagu, alginat, kitosan dan gelatin. Bahan tambahan yang digunakan adalah Carboxymethylcelullosa (CMC), akuades sebagai pelarut, gliserol sebagai plastisizer. Uji coba pembuatan film dilakukan dengan perlakuan bahan plastisizer yaitu gliserol ( 3 dan $5 \mathrm{~g}$ ) dan CMC (0,5 dan $1 \mathrm{~g}$ ) (Tabel 1). Pengamatan yang dilakukan adalah karakteristik fisik edible film secara visual.

Tahap II. Penelitian Tahap II dilakukan berdasarkan karakteristik film pada penelitian tahap I. Formula yang digunakan merupakan hasil perbaikan, sedangkan proses pembuatan film mengacu pada proses pembuatan film tahap sebelumnya. Tabel 6,7 dan 8 merupakan formula yang digunakan dalam uji coba tahap II.

Pengamatan yang dilakukan meliputi: Karakterisasi film secara visual, karakteristik fisik yang meliputi viskositas, Aw, ketebalan, kuat tarik, water vapour transmission rate (WVTR), elongasi, dan pertumbuhan mikroba. Formulasi edible film terbaik digunakan pada tahapan selanjutnya untuk ditambahkan dengan bahan aktif terpilih.

Tabel 1. Formulasi uji coba tahap I, edible film berbahan baku tapioka

(formulation for step I trials, edible films made from cassava starch)

\begin{tabular}{ccccc}
\hline \hline $\begin{array}{c}\text { Formulasi } \\
\text { (formulation) }\end{array}$ & $\begin{array}{c}\text { Tapioka }(\mathrm{g}) \text { (cassava } \\
\text { starch }(\mathrm{g}))\end{array}$ & $\begin{array}{c}\text { Carboxymethyl- } \\
\text { celullosa }(\mathrm{g})\end{array}$ & $\begin{array}{c}\text { Gliserol }(\mathrm{g}) \\
(\text { glycerol }(\mathrm{g}) \text { ) }\end{array}$ & $\begin{array}{c}\text { Akuades }(\mathrm{g}) \\
\text { (aquadest }(\mathrm{g}) \text { ) }\end{array}$ \\
\hline A & 8 & 0,5 & 3 & 88,5 \\
B & 8 & 0,5 & 5 & 86,5 \\
C & 8 & 1 & 3 & 88 \\
D & 8 & 1 & 5 & 86 \\
\hline
\end{tabular}

Tabel 2. Formulasi uji coba tahap I, edible film berbahan baku sagu aren (formulation for step I trials, edible films made from sago)

\begin{tabular}{ccccc}
\hline \hline $\begin{array}{c}\text { Formulasi } \\
\text { formulation })\end{array}$ & $\begin{array}{c}\text { Sagu aren }(\mathrm{g})(\text { sago } \\
\text { palm }(\mathrm{g}))\end{array}$ & $\begin{array}{c}\text { Carboxymethyl- } \\
\text { celullosa }(\mathrm{g})\end{array}$ & $\begin{array}{c}\text { Gliserol }(\mathrm{g}) \\
(\text { glycerol }(\mathrm{g}))\end{array}$ & $\begin{array}{c}\text { Akuades }(\mathrm{g}) \\
\text { (aquadest }(\mathrm{g}))\end{array}$ \\
\hline $\mathrm{E}$ & 8 & 0,5 & 3 & 88,5 \\
$\mathrm{~F}$ & 8 & 0,5 & 5 & 86,5 \\
$\mathrm{G}$ & 8 & 1 & 3 & 88 \\
$\mathrm{H}$ & 8 & 1 & 5 & 86 \\
\hline
\end{tabular}

Tabel 3. Formulasi uji coba tahap I, edible film berbahan baku alginat (formulation for step I trials, edible films made from alginate)

\begin{tabular}{ccccc}
\hline \hline $\begin{array}{c}\text { Formulasi } \\
\text { (formulation) }\end{array}$ & Pati $(\mathrm{g})($ starch $(\mathrm{g}))$ & $\begin{array}{c}\text { Carboxymethyl- } \\
\text { celullosa }(\mathrm{g})\end{array}$ & $\begin{array}{c}\text { Gliserol }(\mathrm{g}) \\
(\text { glycerol }(\mathrm{g}))\end{array}$ & $\begin{array}{c}\text { Akuades }(\mathrm{g}) \\
\text { (aquadest }(\mathrm{g}))\end{array}$ \\
\hline $\mathrm{I}$ & 8 & 0,5 & 3 & 88,5 \\
$\mathrm{~J}$ & 8 & 0,5 & 5 & 86,5 \\
$\mathrm{~K}$ & 8 & 1 & 3 & 88 \\
$\mathrm{~L}$ & 8 & 1 & 5 & 86 \\
\hline
\end{tabular}

Tabel 4. Formulasi uji coba tahap I, edible film berbahan baku kitosan (formulation for step I trials, edible films made from chitosan)

\begin{tabular}{|c|c|c|c|}
\hline $\begin{array}{c}\text { Formulasi } \\
\text { (formulation) }\end{array}$ & Kitosan $(\mathrm{g})($ chitosan $(g))$ & Asam asetat $1 \%$ (acetic acid 1\%) & $\begin{array}{c}\text { Gliserol }(\mathrm{g}) \\
(\text { glycerol }(\mathrm{g}))\end{array}$ \\
\hline $\mathrm{M}$ & 1 & 96 & 3 \\
\hline $\mathrm{N}$ & 2 & 95 & 3 \\
\hline
\end{tabular}


Tabel 5. Formulasi uji coba tahap I, edible film berbahan baku gelatin (formulation for step I trials, edible films made from gelatin)

\begin{tabular}{cccc}
\hline \hline $\begin{array}{c}\text { Formulasi } \\
(\text { formulation })\end{array}$ & Gelatin $(\mathrm{g})$ (gelatin $(\mathrm{g}))$ & Alginat $(\mathrm{g})($ alginate $(\mathrm{g}))$ & Gliserol $(\mathrm{g})(\mathrm{glycerol}(\mathrm{g}))$ \\
\hline $\mathrm{O}$ & $94^{* *}$ & 3 & 3 \\
$\mathrm{P}$ & $92^{* *}$ & 3 & 5 \\
$\mathrm{Q}$ & $94^{*}$ & 3 & 3 \\
$\mathrm{R}$ & $92^{*}$ & 3 & 5 \\
\hline${ }^{* *}:$ gelatin kaki ayam yang diekstrasi dengan air $(1: 3 \mathrm{~b} / \mathrm{v})($ chicken feet gelatin extracted with water $(1: 3 \mathrm{w} / \mathrm{v}))$. \\
${ }^{*}$ gelatin kaki ayam yang diekstrasi dengan asam asetat $1 \%(1: 3 \mathrm{~b} / \mathrm{v})($ chicken feet gelatin extracted with acetic acid $1 \%$ \\
$(1: 3 \mathrm{w} / \mathrm{v}))$.
\end{tabular}

Tabel 6. Formulasi edible film berbahan sagu aren (formulation of edible film made from sago palm)

\begin{tabular}{ccccc}
\hline \hline Formulasi (formulation) & $\begin{array}{c}\text { Sagu aren (g) } \\
\text { (sago palm (g) }\end{array}$ & $\begin{array}{c}\text { Carboxymethyl } \\
\text { celullosa }(\mathrm{g})\end{array}$ & $\begin{array}{c}\text { Gliserol (g) } \\
\text { (glycerol (g)) }\end{array}$ & $\begin{array}{c}\text { Akuades (g) } \\
\text { (aquadest (g)) }\end{array}$ \\
\hline E & 8 & 1 & 5 & 90 \\
F & 8 & 1 & 3 & 92 \\
G & 8 & 0,5 & 5 & 90,5 \\
H & 8 & 0,5 & 3 & 92,5 \\
\hline
\end{tabular}

Tabel 7. Formulasi edible film berbahan baku alginat (formulation of edible film made from alginate)

\begin{tabular}{ccccc}
\hline \hline $\begin{array}{c}\text { Formulasi } \\
\text { (formulation) }\end{array}$ & $\begin{array}{c}\text { Alginat }(\mathrm{g}) \\
\text { (alginate }(\mathrm{g}))\end{array}$ & $\begin{array}{c}\text { Carboxymethyl } \\
\text { celullosa }(\mathrm{g})\end{array}$ & $\begin{array}{c}\text { Gliserol }(\mathrm{g}) \\
\text { (glycerol }(\mathrm{g}))\end{array}$ & $\begin{array}{c}\text { Akuades }(\mathrm{g}) \\
(\text { aquadest }(\mathrm{g}))\end{array}$ \\
\hline $\mathrm{I}$ & 4 & 1 & 5 & 86 \\
$\mathrm{~J}$ & 4 & 1 & 3 & 88 \\
$\mathrm{~K}$ & 4 & 0,5 & 5 & 86,5 \\
$\mathrm{~L}$ & 4 & 0,5 & 3 & 88,5 \\
\hline
\end{tabular}

Tabel 8. Formulasi edible film berbahan baku gelatin kaki ayam (formulation of edible film made from chicken feet gelatin extracted)

\begin{tabular}{cccc}
\hline \hline $\begin{array}{c}\text { Formulasi } \\
\text { formulation })\end{array}$ & Gelatin $(\mathrm{g})($ gelatin $(g))$ & Alginat $(\mathrm{g})($ alginate $(g))$ & Gliserol $(\mathrm{g})($ glycerol $(g))$ \\
\hline $\mathrm{Q}$ & 92 & 3 & 5 \\
$\mathrm{R}$ & 94 & 3 & 3 \\
$\mathrm{~S}$ & 93 & 2 & 5 \\
$\mathrm{~T}$ & 95 & 2 & 3 \\
\hline
\end{tabular}

Cara mengukur kuat tarik:

Kuat tarik $(F)=F / A$

$\mathrm{F}=$ gaya tarik (kgf)

$A=$ luas area lahan yang dilewati uap air $\left(\mathrm{m}^{2}\right)$

$\mathrm{t}=$ waktu (jam)

$\%$ Elongasi:

$\%$ elongasi $=($ panjang setelah putuspanjang awal)/panjang awal x $100 \%$

Water vapour transmission rate (WVTR): WVTR $=\mathrm{m} / \mathrm{A} \times \mathrm{t}$

$\mathrm{m}=$ massa uap air yang melewati bahan $(\mathrm{g})$

$A=$ luas alas sampel $\left(\mathrm{cm}^{2}\right)$

Pembuatan edible film antimikroba. Edible film antimikroba dibuat menggunakan formula terbaik dari proses pembuatan edible film yang telah dilakukan sebelumnya.
Pembuatan larutan untuk edible film dilakukan sama dengan prosedur di atas, namun diberi penambahan antimikroba ekstrak bawang putih segar. Tahap penambahan ekstrak bawang putih segar dilakukan setelah penambahan gliserol dan sebelum dikeringkan oven.

Uji coba pendahuluan aplikasi edible film pada daging sapi. Uji coba aplikasi edible film antimikroba dilakukan dengan melakukan pencelupan pada larutan edible film yang sudah diberi antimikroba. Potongan daging seberat $75 \mathrm{~g}$ bagian has dalam dicelupkan pada larutan edible film antimikroba selama 1 menit, kemudian dimasukkan ke dalam freezer untuk membantu proses penyerapan larutan film tersebut ke dalam daging selama 1 jam. Daging yang sudah dicoating, diletakkan ke dalam tray, dan 
dilakukan penyimpanan. Perlakuan penyimpanan adalah suhu $4-5^{\circ} \mathrm{C}$ (refrigerator) dan suhu $0-4^{\circ} \mathrm{C}$ (freezer). Pengamatan dilakukan setiap minggu sekali, dengan parameter pengamatan yang dilakukan adalah Aw, viskositas larutan, warna, karakteristik fisik edible film (kuat tarik, RH, elongasi, WVTR, ketebalan dan kadar air), uji kemampuan hambat terhadap bakteri uji ( $E$. coli dan $S$. aureus).

\section{Hasil dan Pembahasan}

\section{Karakteristik bahan baku}

Hasil karakterisasi terlihat pada Tabel 9. Antimikroba yang digunakan berasal dari ekstrak segar bawang putih. Proses ekstraksi bawang putih segar dilakukan menggunakan metode maserasi dengan pelarut air.Teknik maserasi dipilih karena merupakan metode ekstraksi yang paling sederhana dan baik digunakan untuk simplisia yang mengandung zat aktif yang tidak tahan terhadap suhu tinggi.

Tabel 9 menunjukkan komposisi bahan baku yang digunakan dalam pembuatan edible film. Karbohidrat merupakan komponen utama pada tapioka, sagu aren dan alginat sedangkan protein merupakan komponen utama pada kitosan dan gelatin. Edible film dari polisakarida (karbohidrat) dan protein memiliki banyak keuntungan seperti biodegradabel, edibel (dapat dimakan), biokompatibel, penampilan yang estetis, dan kemampuannya sebagai penghalang (barrier) terhadap oksigen dan tekanan fisik selama transportasi dan penyimpanan. Gelatin dan alginat mempunyai kelebihan berkaitan dengan sifat koloid dan kemampuannya untuk membentuk gel yang kuat atau polimer yang tidak larut terhadap reaksi dengan logamlogam multivalensi, sehingga diduga sangat sesuai digunakan sebagai edible film dan pelapis (coating) pada makanan (Tapia et al., 2007). Namun plastisizer diperlukan untuk meningkatkan fleksibilitas film pada pembuatan edible film berbasis polisakarida dan protein.

Berdasarkan pengamatan secara fisik dan tingkat kemudahan dalam melepas film dari plat kaca pada tahap uji coba formula menunjukkan bahwa formula berbahan karbohidrat (Gambar 1), bahan baku tapioka memiliki tingkat kelengketan yang sangat tinggi sehingga sulit dilepaskan dari plat kaca atau film mudah sobek.

Tabel 9. Hasil analisis proksimat bahan baku edible film

(the results of the proximate analysis of raw materials of edible film)

\begin{tabular}{lccccc}
\hline \hline $\begin{array}{c}\text { Bahan baku } \\
\text { (raw material) }\end{array}$ & $\begin{array}{c}\text { Air (\%) } \\
(\text { water (\%)) }\end{array}$ & $\begin{array}{c}\text { Abu (\%) } \\
(\text { ash (\%)) }\end{array}$ & $\begin{array}{c}\text { Protein (\%) } \\
\text { (protein (\%)) }\end{array}$ & $\begin{array}{c}\text { Lemak (\%) } \\
\text { (lipid (\%)) }\end{array}$ & $\begin{array}{c}\text { Karbohidrat (\%) } \\
\text { (carbohydrate (\%)) }\end{array}$ \\
\hline Tapioka (cassava) & 13,91 & 0,12 & 0,50 & 0,24 & 85,23 \\
Sagu aren (sago palm) & 17,38 & 0,25 & 1,06 & 0,85 & 80,46 \\
Alginat (alginate) & 15,47 & 39,47 & 1,27 & 0,28 & 43,51 \\
Kitosan (chitosan) & 10,38 & 0,26 & 43,00 & 0,69 & 45,67 \\
Gelatin (gelatin) & 6,13 & 0,86 & 88,17 & 4,08 & 0,76 \\
\hline
\end{tabular}

Tabel 10. Karakteristik fisik formula edible film

(the physical characteristics of the edible film formula)

\begin{tabular}{|c|c|c|c|c|c|c|}
\hline \multirow{2}{*}{$\begin{array}{l}\text { Formula } \\
\text { (formula) }\end{array}$} & \multicolumn{6}{|c|}{ Parameter } \\
\hline & $\begin{array}{c}\text { WVTR } \\
\left(\mathrm{g} / \mathrm{m}^{2} / \mathrm{jam}\right)\end{array}$ & $\begin{array}{l}\mathrm{RH} \\
(\%)\end{array}$ & $\begin{array}{c}\text { Elongasi }(\mathrm{mm}) \\
\text { (elongation } \\
(\mathrm{mm}))\end{array}$ & $\begin{array}{l}\text { Kuat tarik (kgf) } \\
\text { (tensile } \\
\text { strength }(\mathrm{kg}))\end{array}$ & $\begin{array}{l}\text { Ketebalan film }(\mathrm{mm}) \\
(\text { film thickness }(\mathrm{mm}))\end{array}$ & $\begin{array}{c}\text { Kadar air (\%) } \\
\text { (water } \\
\text { content }(\%))\end{array}$ \\
\hline$E$ & 13,62 & 65,0 & 25 & $<0,1$ & 0,04 & 26,57 \\
\hline $\mathrm{F}$ & 11,16 & 64,7 & 55 & $<0,1$ & 0,08 & 16,55 \\
\hline $\mathrm{G}$ & 14,21 & 73,5 & 30 & $<0,1$ & 0,08 & 17,35 \\
\hline $\mathrm{H}$ & 8,50 & 73,2 & 20 & $<0,1$ & 0,08 & 17,07 \\
\hline I & 15,35 & 63,5 & 50 & $<0,1$ & 0,07 & 24,59 \\
\hline$J$ & 13,60 & 64,3 & 300 & $<0,1$ & 0,06 & 20,00 \\
\hline $\mathrm{K}$ & 11,66 & 73,7 & 30 & $<0,1$ & 0,04 & 24,14 \\
\hline $\mathrm{L}$ & 9,87 & 75,2 & 30 & $<0,1$ & 0,06 & 21,82 \\
\hline$Q$ & 22,91 & 65,3 & 40 & $<0,1$ & 0,07 & 22,22 \\
\hline $\mathrm{R}$ & 15,80 & 65,0 & 30 & $<0,1$ & 0,05 & 19,05 \\
\hline $\mathrm{S}$ & 21,18 & 64,0 & 25 & $<0,1$ & 0,05 & 20,69 \\
\hline $\mathrm{T}$ & 15,49 & 69,5 & 20 & $<0,1$ & 0,06 & 22,73 \\
\hline
\end{tabular}

WVTR: laju transmisi uap air (water vapour transmission rate).

$\mathrm{RH}$ : relative humidity (kelembaban). 


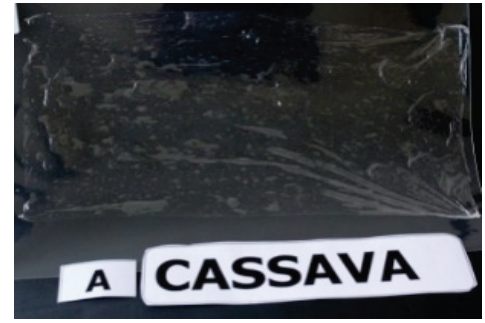

A. Edibel film berbasis cassava formula A (edible film based cassava formula $A$ )

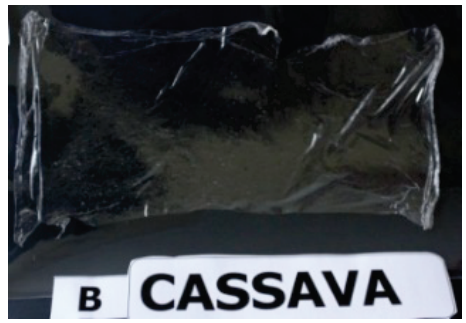

B. Edibel film berbasis cassava formula B (edible film based cassava formula $B$ )

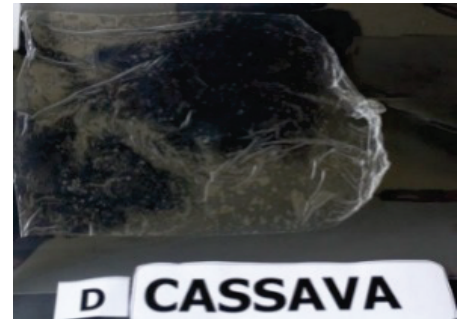

D. Edibel film berbasis cassava formula $\mathrm{D}$ (edible film based cassava formula $D$ )

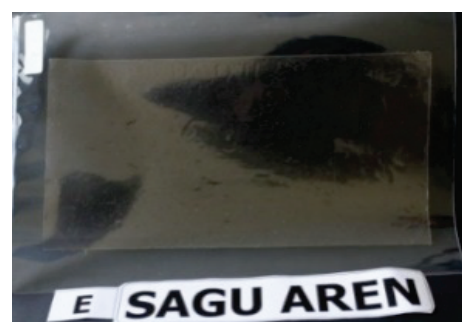

E. Edibel film berbasis sagu formula $E$ (edible film based sago formula $E$ )

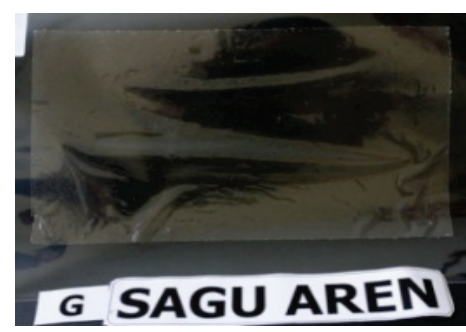

G. Edibel film berbasis sagu formula $G$ (edible film based sago formula $G$ )

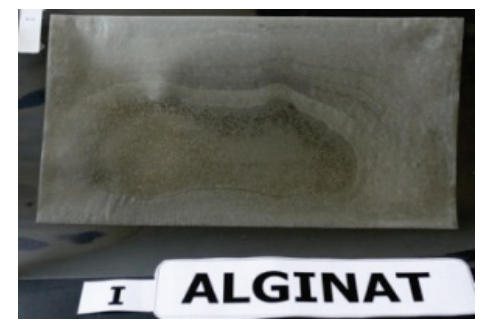

I. Edibel film berbasis alginat formula I (edible film based alginate formula I)

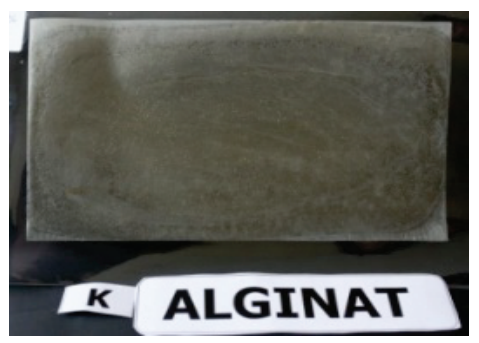

$\mathrm{K}$. Edibel film berbasis alginat formula $\mathrm{K}$ (edible film based alginate formula $K$ )

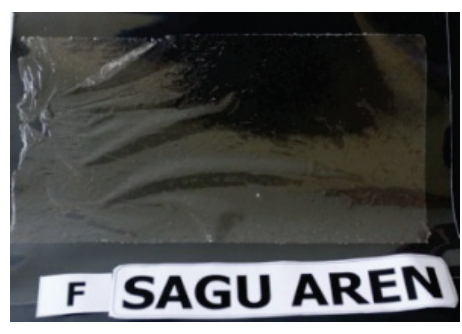

F. Edibel film berbasis sagu formula $F$ (edible film based sago formula $F$ )

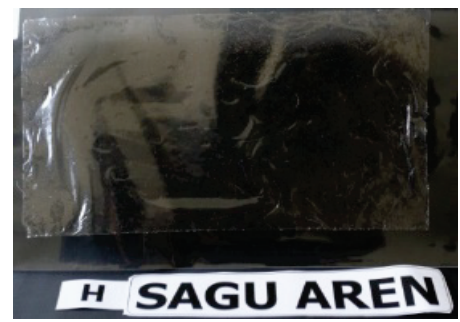

$\mathrm{H}$. Edibel film berbasis sagu formula $\mathrm{H}$ (edible film based sago formula $A$ )

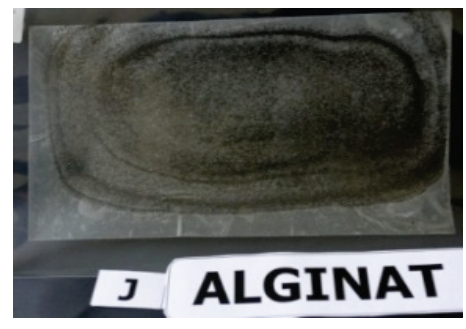

$\mathrm{J}$. Edibel film berbasis alginat formula $\mathrm{J}$ (edible film based alginate formula J)

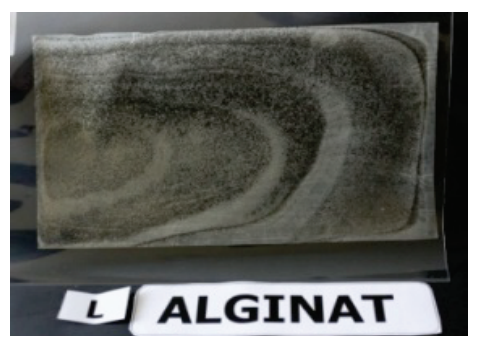

L. Edibel film berbasis alginat formula $L$ (edible film based alginate formula $L$ )

Gambar 1. Edible film yang dihasilkan dari formula berbahan dasar karbohidrat yang diujicobakan (edible films produced based on carbohydrate ingredients of the tested formula). 
Film berbasis karbohidrat lainnya yaitu sagu aren dan alginat (Gambar 1) menunjukkan karakteristik yang lebih baik dibandingkan dengan film berbahan baku tapioka. Kriteria edible film yang diinginkan yaitu film tidak mudah sobek dan elastis. Film berbasis

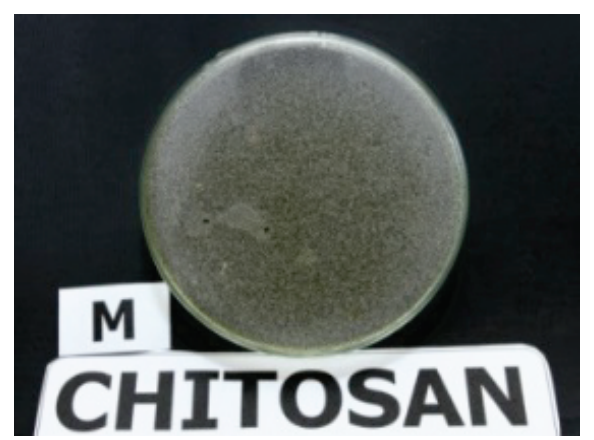

M. Edibel film berbasis kitosan formula M (edible film based chitosan formula $M$ )

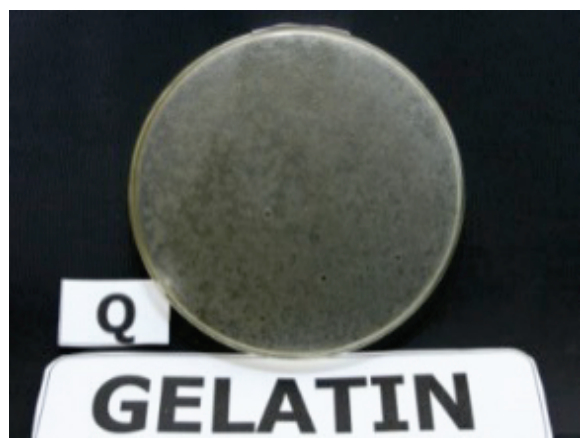

Q. Edibel film berbasis gelatin formula $Q$ (edible film based gelatin formula $Q$ )

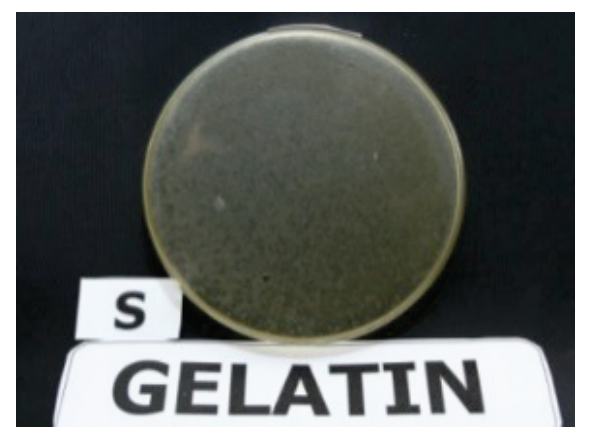

S. Edibel film berbasis gelatin formula $\mathrm{S}$ (edible film based gelatin formula $S$ ) protein (Gambar 2), dengan bahan baku khitosan menghasilkan film yang bersifat keras dan susah dilepas dari plat film walaupun dengan penambahan gliserol $1 \mathrm{~g}$ menghasilkan film yang cukup baik (edible film M dan N pada Gambar 2).

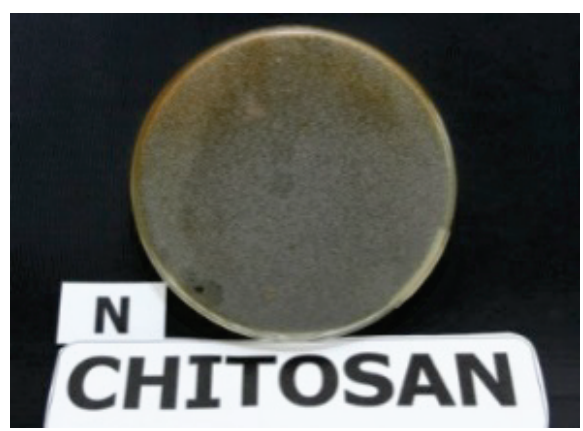

N. Edibel film berbasis kitosan formula $\mathrm{N}$ (edible film based chitosan formula $N$ )

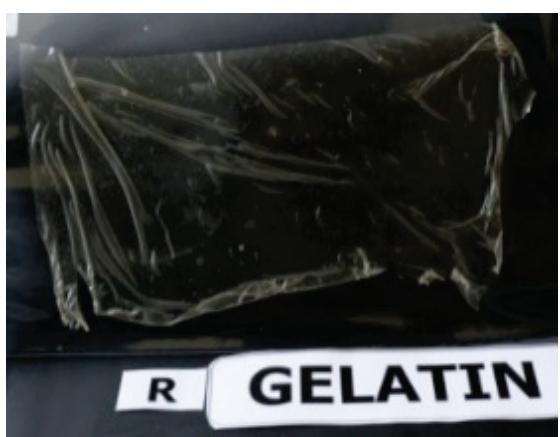

R. Edibel film berbasis gelatin formula $\mathrm{R}$ (edible film based gelatin formula $R$ )

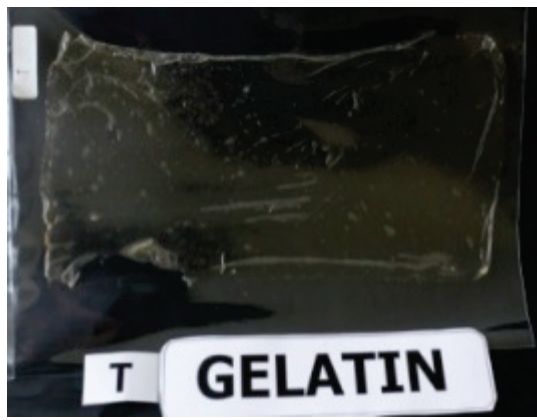

T. Edibel film berbasis gelatin formula $\mathrm{T}$ (edible film based gelatin formula $T$ )

Gambar 2. Edible film yang dihasilkan dari formula berbahan dasar protein yang diujicobakan (edible films produced based on protein ingredients of the tested formula). 


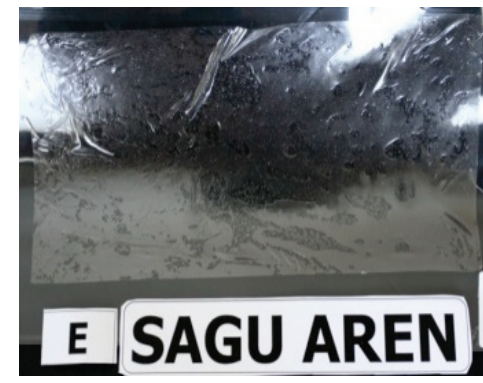

E. Edibel film berbasis sagu aren formula $\mathrm{E}$ (edible film based sago palm formula $E$ )

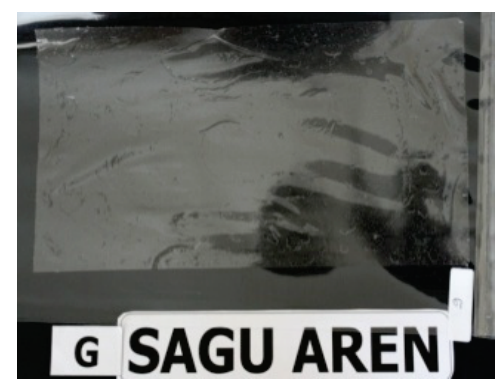

G. Edibel film berbasis sagu aren formula $\mathrm{G}$ (edible film based sago palm formula $G$ )

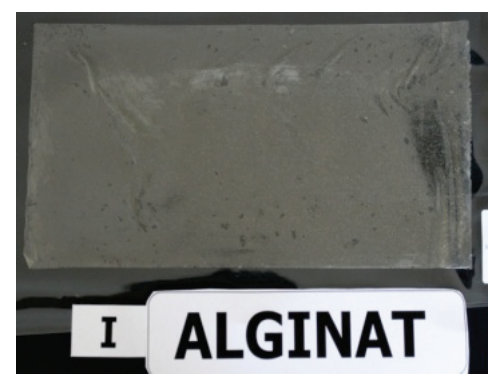

I. Edibel film berbasis alginat formula I (edible film based alginate palm formula $I$ )

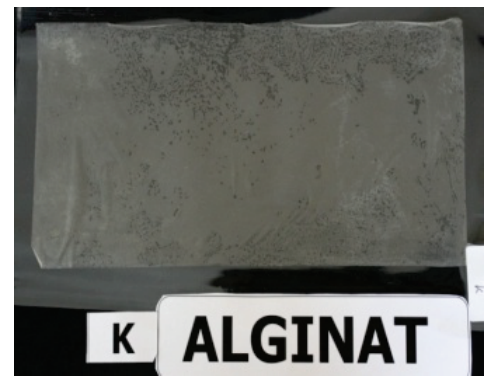

K. Edibel film berbasis alginat formula K (edible film based alginate palm formula $K$ )

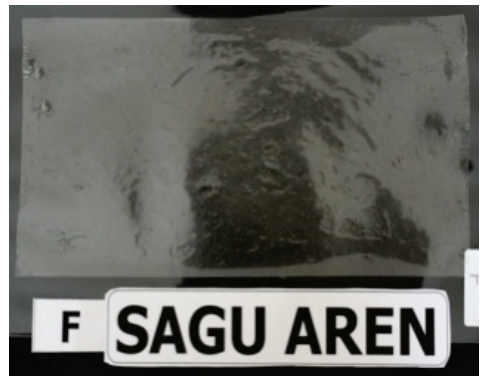

F. Edibel film berbasis sagu aren formula $\mathrm{F}$ (edible film based sago palm formula $F$ )

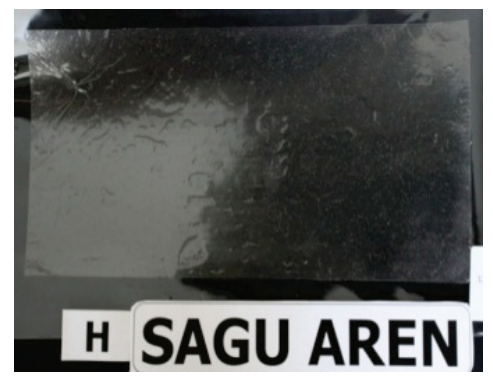

H. Edibel film berbasis sagu aren formula $\mathrm{H}$ (edible film based sago palm formula $H$ )

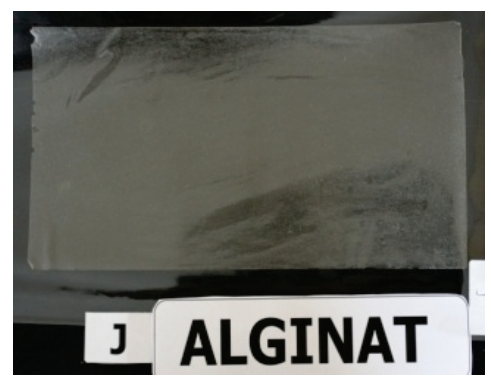

$\mathrm{J}$. Edibel film berbasis alginat formula J (edible film based alginate palm formula $J$ )

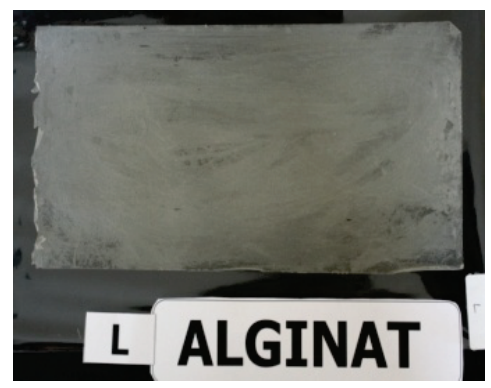

L. Edibel film berbasis alginat formula $L$ (edible film based alginate palm formula $L$ )

Gambar 3. Edible film yang dihasilkan dari perbaikan formula berbahan baku karbohidrat (edible films produced based on carbohydrate of the improved formula). 


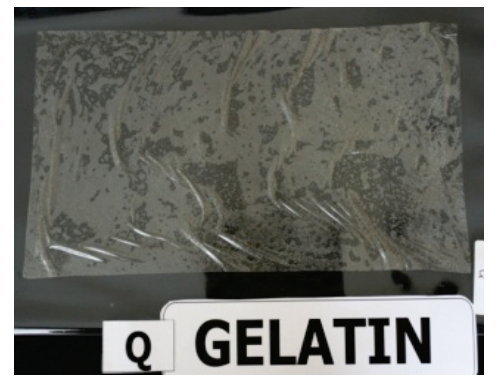

Q. Edibel film berbasis gelatin formula $Q$ (edible film based gelatin palm formula $Q$ )

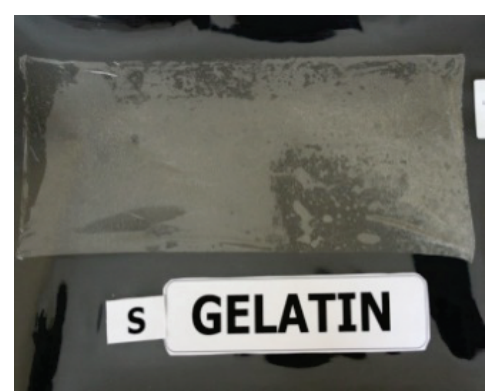

S. Edibel film berbasis gelatin formula $S$ (edible film based gelatin palm formula $S$

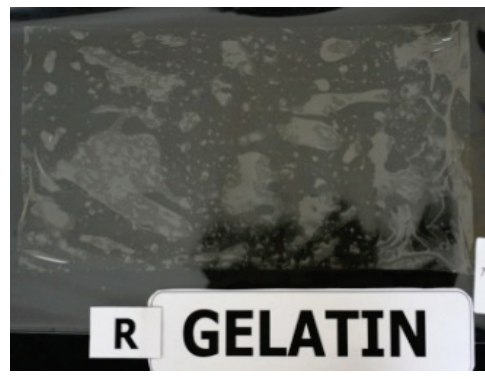

R. Edibel film berbasis gelatin formula R (edible film based gelatin palm formula $R$ )

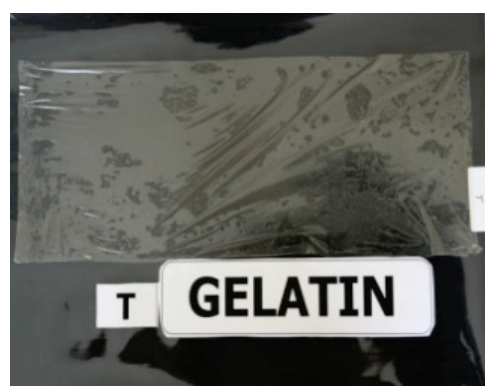

T. Edibel film berbasis gelatin formula T (edible film based gelatin palm formula $T$ )

Gambar 4. Edible film yang dihasilkan dari perbaikan formula berbahan baku gelatin (edible films produced based on gelatin of the improved formula).

Proses ekstraksi gelatin dari kaki ayam berpengaruh terhadap larutan gelatin yang dihasilkan dan karakteristik film. Ekstraksi dengan asam asetat $1 \%$ selama 24 jam (1:3 b/v) menghasilkan ekstrak 3-4× lebih banyak dibandingkan ekstrak secara langsung menggunakan air, demikian juga karakteristik film yang dihasilkan lebih baik (edible film $S$ dan $Q$ pada Gambar 2). Film berbahan baku gelatin memerlukan tambahan alginat supaya dihasilkan film yang bersifat lentur. Berdasarkan hasil pengamatan fisik pada penelitian tahap I (uji coba formula) disimpulkan untuk tahapan selanjutnya difokuskan pada perbaikan formula film berbahan baku karbohidrat yaitu sagu aren dan alginat, sedangkan berbahan baku protein yaitu formula gelatin.

Pada penelitian tahap II dilakukan perbaikan formula edible film terpilih dari tahap uji coba. Gambar 3 dan 4 menunjukkan visualisasi karakteristik edible film hasil perbaikan formula. Edible film yang diperoleh memiliki nilai aktivitas air (Aw), viskositas dan warna (kecerahan) seperti disajikan dalam
Gambar 5. Aktivitas air (Aw) edible film bervariasi, Aw yang terkecil dimiliki oleh formula $\mathrm{H}$ dan $\mathrm{T}$ yaitu 0,526 dan yang tertinggi dimiliki oleh formula $R(0,538)$ sebagaimana disajikan pada Gambar 5. Aktivitas air (Aw) menggambarkan jumlah air yang menjadi batas mikroorganisme masih dapat hidup. Aw juga merupakan jumlah air bebas yang dapat digunakan oleh mikroorganisme untuk pertumbuhannya. Berbagai mikroorganisme mempunyai Aw minimum agar dapat tumbuh dengan baik, misalnya bakteri memiliki Aw 0,90; khamir 0,80-0,90; dan kapang 0,60-0,70 (Winarno, 1997). Pada edible film yang dihasilkan dari penelitian ini, terlihat nilai Aw yang dimiliki masih dalam batas aman untuk penyimpanan. Ini berarti edible film yang dihasilkan layak untuk dijadikan bahan pelapis (coating) pada makanan.

Viskositas (kekentalan) larutan edible film yang dihasilkan terlihat pada Gambar 5 . Kekentalan yang paling rendah dimiliki oleh formula S (4120 cP/menit) dan T (4280 $\mathrm{cP} /$ menit) dan tertinggi dimiliki oleh formula $\mathrm{J}$ (31000 cP/menit). Viskositas yang rendah 
menggambarkan bahwa formula $\mathrm{S}$ dan $\mathrm{T}$ cukup encer sehingga ketika dilapiskan pada daging dapat menempel dengan sempurna, sedangkan viskositas yang tinggi menggambarkan bahwa formula $\mathrm{J}$ sangat kental sehingga ketika dilapiskan pada daging paprika menjadi sangat tebal dan tidak mudah kering.
Parameter warna (yang dinotasikan dengan $L=$ tingkat kecerahan), dapat dilihat bahwa edible film formula $\mathrm{H}$ memiliki nilai $\mathrm{L}$ yang paling tinggi di antara semua formula dengan nilai L 98,01 (Gambar 3). Nilai L adalah antara 0-100. Hal ini menunjukkan bahwa edible film yang dihasilkan pada kisaran yang cerah.

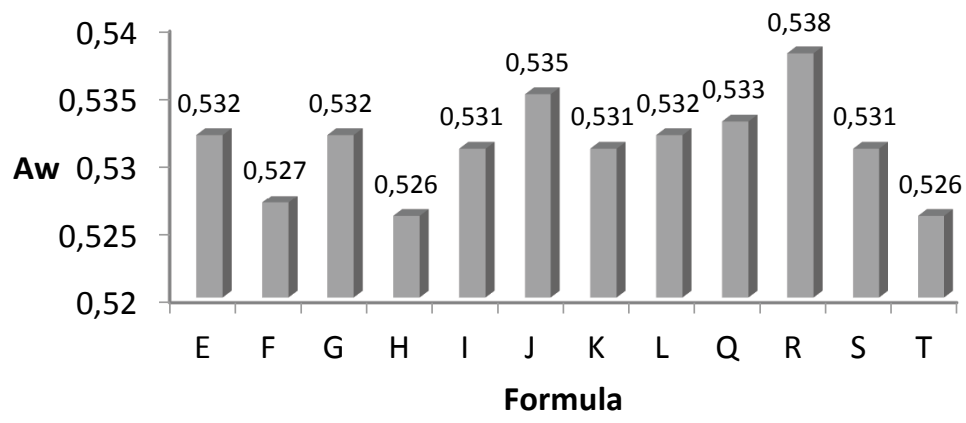

(a)

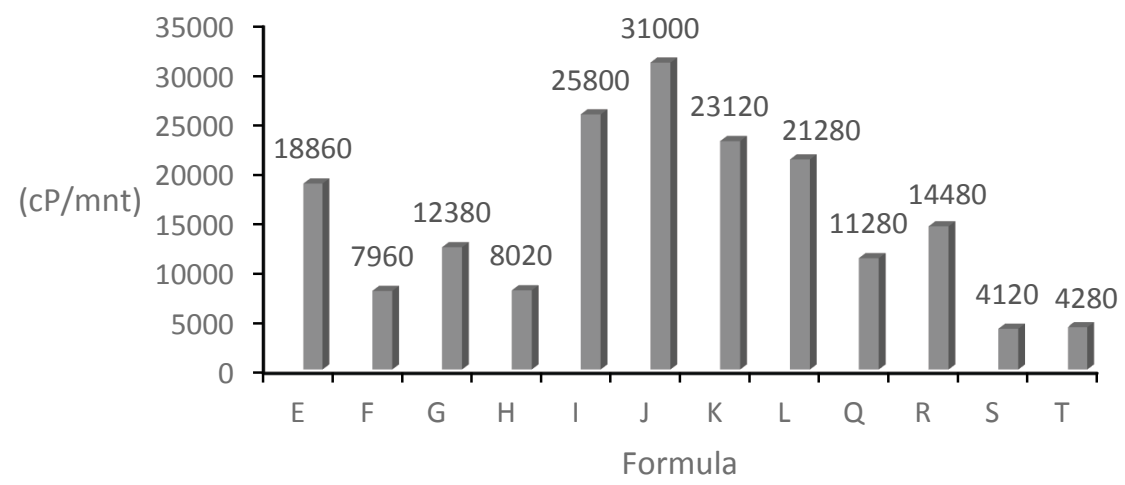

(b)

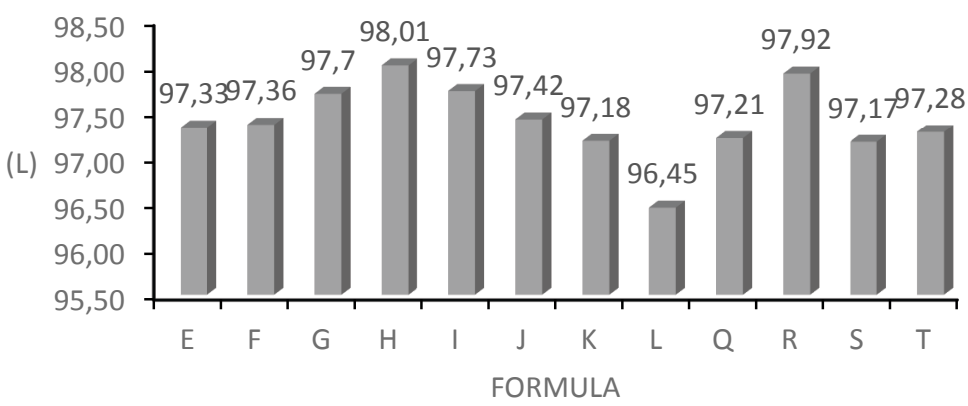

(c)

Gambar 5. Pengaruh formula edible film terhadap (a) Aw, (b) viskositas, (c) warna (the effect of edible film formulation to (a) Aw, (b) viscocity, (c) color). 
Tabel 10 menunjukkan bahwa secara umum formula $\mathrm{H}$, $\mathrm{L}$ dan $\mathrm{T}$ memiliki laju transmisi uap air yang lebih rendah, masing-masing 8,$50 ; 9,87 ; 15,49 \mathrm{~g} / \mathrm{m}^{2} / \mathrm{jam}$, bila dibanding formula lainnya. Laju transmisi yang terbesar pada formula $Q$ dan $S$. Masingmasing 22,91 dan 21,18 $\mathrm{g} / \mathrm{m}^{2} / \mathrm{jam}$. Laju transmisi uap air (WVTR) menunjukkan kemampuan edible film dalam menahan laju penguapan uap air. Pada parameter kuat tarik menunjukkan semua formula yang diuji mempunyai kuat tarik yang sama yaitu $<0,1$ kgf, sedangkan ketebalan film berkisar antara 0,04-0,08 $\mathrm{mm}$, terlihat bahwa film yang terbuat dari gelatin kaki ayam mempunyai ketebalan film yang rendah.

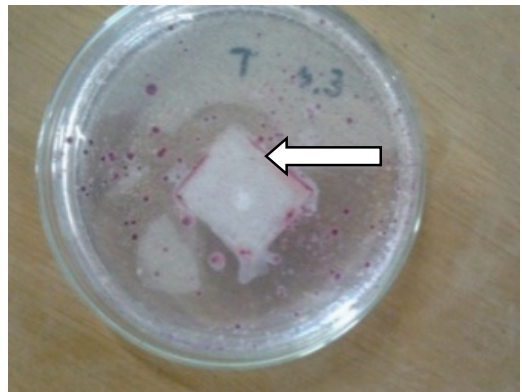

(a) E. coli

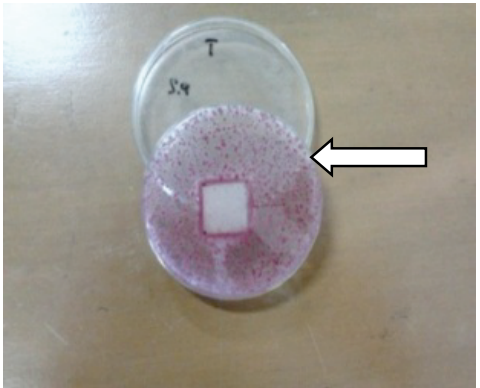

(b) S. aureus

Gambar 6. Uji daya hambat film antimikroba terhadap bakteri uji (a) E. coli, (b) S. aureus. Tanda panah menunjukkan zona hambat (antimicrobial films inhibition test against bacteria growth (a) E. coli, (b) S. aureus. Arrow show inhibition zone).

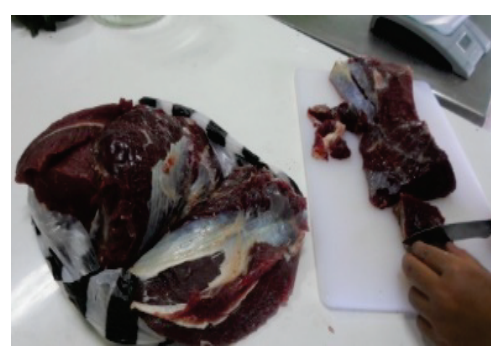

(a)

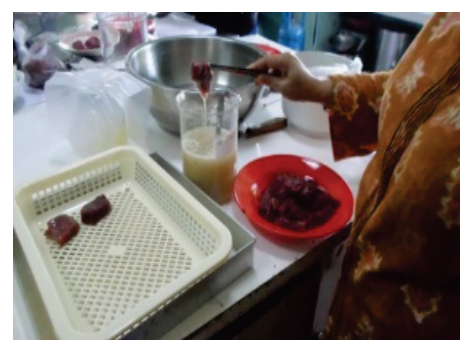

(b)

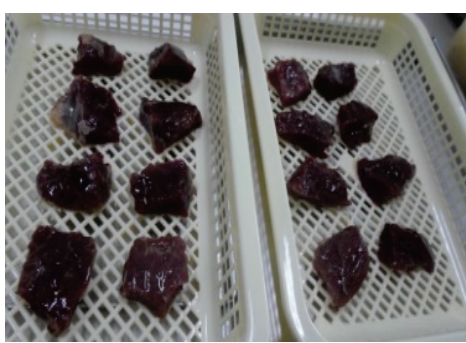

(c)
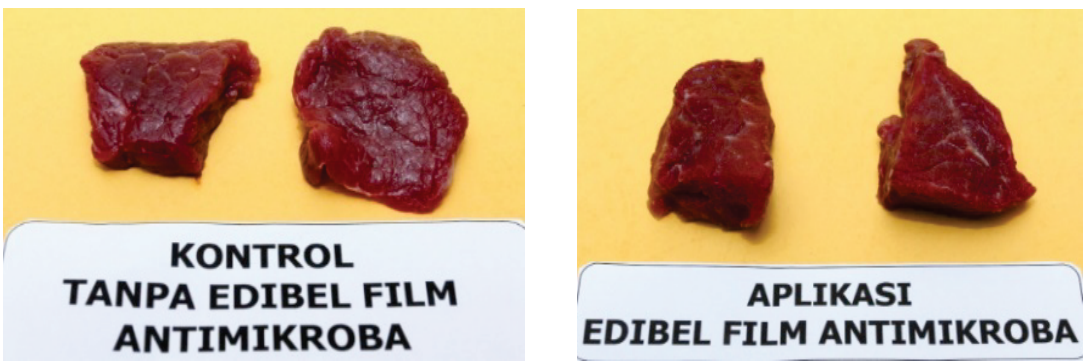

Gambar 7. Tahap uji pendahuluan aplikasi edibel film antimikroba berbasis gelatin kaki ayam

(a) pengirisan daging, (b) pencelupan dalam larutan edibel film, (c) daging yang dilapisi edibel film (preliminary study applications meat coated gelatin-based antimicrobial edible film chicken feet (a) meat cutting, (b) meat dyeing, (c) meat coating). 


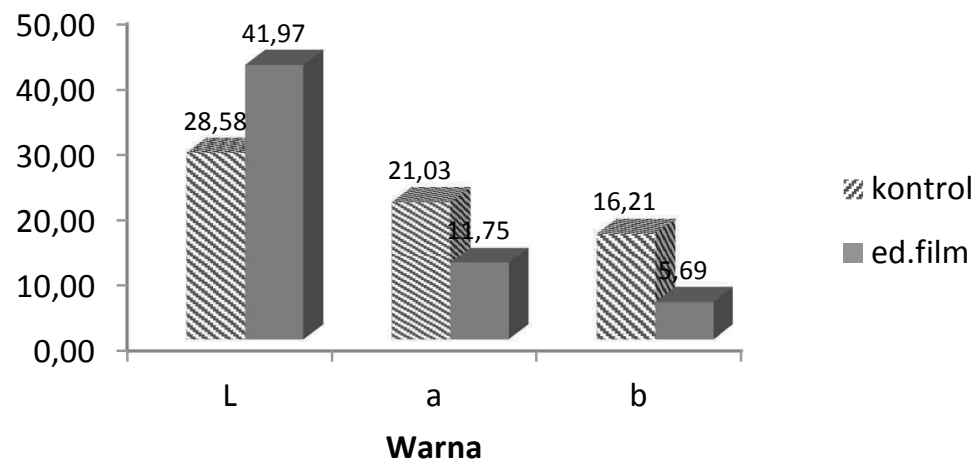

Gambar 8. Pengaruh edible coating antimikroba terhadap warna daging sapi. $\mathrm{L}=$ kecerahan, $a=$ gradasi spektrum warna antara hijau dan merah, $b=$ gradasi spektrum warna antara biru dan kuning (effect of antimicrobial edible coating on the color of beef. $L=$ brightness, a= spectrum gradation between green and red, $b=$ spectrum gradation between blue and yellow).

Berdasarkan hasil analisis pada semua parameter sebagaimana ditampilkan pada Tabel 8, terlihat bahwa formula edible film berbahan baku gelatin menunjukkan kemampuan film yang lebih baik dibandingkan film berbahan baku pati. Formula tersebut selanjutnya ditambahkan dengan antimikroba ekstrak bawang putih segar. Hasil pengujian daya hambat pada edible film dengan bahan aktif ekstrak bawang putih terlihat pada Gambar 6, pengujian dilakukan terhadap bakteri uji S.aureus dan E.coli. Hasil pengamatan menunjukkan bahwa pada film antimikroba mampu menghambat pertumbuhan bakteri uji yang ditunjukkan dengan tidak adanya pertumbuhan bakteri uji ( $S$. aureus dan E. coli) pada edible film antimikroba.

Ujicoba aplikasi edible film antimikroba terlihat pada Gambar 7 dan 8 menunjukkan bahwa uji coba aplikasi film antimikroba berbasis gelatin kaki ayam mampu meningkatkankecerahan daging ( $L=41,97)$ dibandingkan dengan warna daging kontrol $(L=28,58)$. Hal ini menunjukkan suatu kelebihan bahwa dengan aplikasi gelatin sebagai edible film mampu mem-perbaiki karakter warna daging sapi.

\section{Kesimpulan}

Formula edible film antimikroba berbasis gelatin kaki ayam merupakan edible film terbaik yang dapat diaplikasikan pada daging. Karakteristik edible film tersebut warna L: 97,28; elongasi $20 \mathrm{~mm}$; kuat tarik <0,1 kgf; ketebalan 0,06 mm; WVTR 15,49 g/(mm.jam);
Aw 0,526; kadar air 22,73\%, dan mempunyai sifat antimikroba (menghambat $S$. aureus dan E. coli). Studi pendahuluan aplikasi pada daging menunjukkan bahwa daging yang diberi edible film mempunyai warna daging lebih cerah L: 41,97 dibandingkan dengan daging segar (kontrol) L 28,58. Edible film berbasis gelatin kaki ayam mempunyai potensi untuk digunakan sebagai pelapis bahan pangan khususnya daging, diperlukan studi yang lebih intensif terhadap kemampuannya dalam menghambat pertumbuhan mikroba.

\section{Daftar Pustaka}

De Padua, L. S., N. Bunyapraphatsara and R. H. M. J. Lemmens. 1999. Plant resources of South-East Asia: Medicinal and poisonous plants 1. 12: 167-175. Backhuys Publishers, Leiden.

Garcia-Lopez, M. L., M. Prieto and A. Otero. 1998. The physiological attributes of gram-negative bacteria associated with spoilage of meat and meat products. A. Davis and R. Board (eds). The Microbiology of Meat and Poultry, Black Academic Professional, London.

Harris, H. 1999. Kajian teknik formulasi terhadap karakteristik edible film dari pati ubi kayu, aren, dan sagu untuk pengemas produk pangan semibasah. Disertasi Program Pasca Sarjana, Institut Pertanian Bogor, Bogor. 
Hermansyah, A. 2006. Kualitas mikrobiologis dan organoleptik daging sapi yang direndam larutan bawang putih (Allium sativum). Skripsi Institut Pertanian Bogor, Bogor.

Indu, M. N., A. A. M. Hatha, C. Abirosh, U. Harshand and G. Vivekanandan. 2006. Antimicrobial activity of some of the south-Indian spices against serotypes of Escheria coli, Salmonella, Listeria monocytogenes and Aeromonas hydrophila. Braz. J. Microbiol. 37: 153158.

Li, P. and M. Brath. 1998. Impact of edible coating on nutritional and physiological changes in lightly-processed carrot. Postharvest Biol. Tec. 14: 51-60.

Mauriello, G. D. L., A. La Storia, F. Villani and D. Ercolini. 2005. Antimicrobial activity of a nisin-activated plastic film for food packaging. Lett. Appl. Microbiol. 41: 464-469.

Newall, C. A., L. A. Anderson and J. D. Phillipson. 1996. Herbal medicines: a guide for health-care professionals. Pharmaceutical Press, London.

Newton, K. G., J. C. L. Harrison and A. M. Wauters. 1978. Sources of psychrotrophic bacteria on meat at the abattoir. J. Appl. Bacteriol. 45: 75-82.
Pranoto, Y., V. M. Salokhe and S. K. Rakshit. 2005. Physical and Antibacterial Properties of Alginate-Based Edible Film Incorporated with Garlic Oil. J. Food Res. Int. 38: 267-272.

Rao, D. N. and B. S. Ramesh. 1992. The microbiology of sheep carcasses processed in modern Indian abattoir. Meat Sci. 32: 425-436.

Roller, S., S. Sagoo, R. Board, T. O'Mahony, E. Caplice, G. Fitzgerald, M. Fogden, M. Owen and H. Fletcher. 2002. Novel combinations of chitosan, carnocin and sulphite for the preservation of chilled pork sausages. Meat Sci. 62: 165-177.

Tapia, M. S., M. A. Rojas-Grau, E. J. Rodriguez, J. Ramirez, A. Carmona and O. M. Belloso. 2007. Alginate and Gellan Based Edible Films for Probiotic Coatings on Fresh-Cut Fruits. J. Food Sci. 72: 190-196.

Zhou, G. H., X. L. Xu and Y. Liu. 2010. Preservation technologies for Fresh Meat-A Review. Meat Sci. 86: 119-129.

Winarno, F. G. 1997. Kimia Pangan dan Gizi. PT. Gramedia Pustaka Utama, Jakarta. 